land. In Escher, A. \& Watt, W. S. (edit.) Geology of Greenland, 404-429. Copenhagen: Geol. Surv. Greenland.

Wager, L. R. 1934: Geological investigations in East Greenland, Part 1. General geology from Angmagsalik to Kap Dalton. Meddr Grønland 105, 2, 46 pp.

H. A.,

Geologisk Institutt,

Allegt. 41,

N-5014 Bergen,

Norway.

B. E. G.,

Department of Geology,

University of Western Ontario,

London, Ontario N6A 5B7,

Canada.
R. C. O. G., Department of Geology, Chelsea College, 271 King Street, London W6 $9 L Z$,

U. $K$.

D. C. R., Department of Earth Sciences, University of Leeds, Leeds LS2 9JT,

\title{
Mapping of Tertiary basalts on the northern Blosseville Kyst, East Greenland
}

\section{W. Stuart Watt and Margrethe Watt}

During the 1978 season work carried out by a helicopter-supported field team was concentrated in the region around Kap Dalton and Stenos Gletscher. The work formed a continuation of that carried out in 1975 in the coastal region between Kap Dalton and Steward $\varnothing$.

The main objectives were to link the stratigraphic sequence of the coastal region to that established for the Scoresby Sund area to the north and north-west. For this it was essential to gain a detailed knowledge of the inland behaviour of the coastal fault system.

\section{Lithostratigraphy}

Stratigraphic correlation in the region is based on 17 traverses totalling $8600 \mathrm{~m}$ of profile covering 1900-1950 m reckoned to be the total succession represented in the area.

For ease of correlation the lavas were divided into lithostratigraphic units based largely on phenocryst size and density combined with characteristic morphological features and colour of the flows.

The lower $650-700 \mathrm{~m}$ consists of sparsely or non-porphyritic flows weathering to a rich red-brown colour and commonly exceeding $50 \mathrm{~m}$ in thickness. Then, without noticable unconformity, a radical change takes place to a group of grey-weathering, often coarser, but usually quite thin flows. These are mixed porphyritic, often with large $(5-10 \mathrm{~cm})$ stellate aggregates of plagioclase and sometimes pyroxene, and non-porphyritic. Both types show marked pahoehoe features, sometimes separated by thin, occasionally fossiliferous, sedi- 
ment horizons. This group, which in the region varies between 200 and $300 \mathrm{~m}$ in thickness, forms an easily recognisable marker horizon with very little lateral variation.

The upper, approximately $1000 \mathrm{~m}$ of the succession, consists of fairly densely plagioclase-porphyritic, and frequently also slightly pyroxene-porphyritic lavas. The plagioclase aggregates are normally small and even sized, decreasing slightly in size and density towards the top of the succession. The lavas described above are all tholeiitic.

It was hoped that lavas correlatable with those immediately underlying the sediments at Kap Dalton (Watt, Soper \& Watt, 1976, p. 121) might occur on the highest peaks $(1700 \mathrm{~m})$ inland from Kap Dalton. However, this was not the case, and although the lava succession preserved below the sediments at Kap Dalton bears some resemblance to the highest lavas in the region their exact stratigraphic position remains undetermined. The succession on the coast can be correlated with the upper half of that in the Scoresby Sund region but appears to be slightly thicker in the coastal region.

\section{Structure of the area}

Partly with the aid of the marker horizon mentioned above it was possible to determine both direction and magnitude of faulting in the region.

While the outer coast east of a shatter zone running in an almost straight line from the Kap Dalton sediments to the inner part of Steward $\varnothing$ is characterised by en echelon block faulting (Watt, Emeleus \& Watt, 1972, p. 81; Watt, M. 1975, p. 92), the area north-west of the shatter zone is broken up into long, narrow blocks by subparallel scissor faulting extending $25 \mathrm{~km}$ inland from the coast. The fault planes are normally near vertical and the maximum throw often in the order of 200-300 m. Locally the scissor faulting has given way to extensive step faulting with minor displacement.

The throw on the major fault responsible for the preservation of the sediments at Kap Dalton, which by Wager (1935) was estimated to exceed $600 \mathrm{~m}$, can now be shown to exceed $1500 \mathrm{~m}$.

\section{Dykes}

Suites of dyke samples were collected covering the approximately $25 \mathrm{~km}$ wide strip inland from the main fault and shatter zone on the coast. As to their setting very little can be added to earlier observations (Watt, M. 1975, 93-94; Watt, Soper \& Watt, 1976, p. 121). In hand sample the dykes resemble the surrounding lavas though the majority are non-porphyritic.

\section{References}

Wager, L. R., 1935: Geological investigations in East Greenland. Part 2. Geology of Kap Dalton. Meddr Grønland 105, 3, 32 pp.

Watt, M. 1975: Photo-reconnaissance of the Blosseville Kyst between Steward Ø and Søkongens Bugt, central East Greenland. Rapp. Grønlands geol. Unders. 75, 91-95.

Watt, W. S., Emeleus, C. H. \& Watt, M. 1972: Preliminary report on the basalts of Volquart Boons Kyst, East Greenland. Rapp. Gronlands geol. Unders. 48, 75-83.

Watt, W. S., Soper, N. J. \& Watt, M. 1976: Reconnaissance mapping of the northern Blosseville Kyst between Kap Brewster and Kap Dalton, central East Greenland. Rapp. Grønlands geol. Unders. 80, $120-122$. 